Egyptian Journal of Aquatic Biology \& Fisheries

Zoology Department, Faculty of Science,

Ain Shams University, Cairo, Egypt.

ISSN $1110-6131$

Vol. 23(2): 213 - 226 (2019)

www.ejabf.journals.ekb.eg

\title{
Evaluation of some tilapia species as biomarkers for pesticides accumulation levels at Lake Edku, Egypt.
}

\author{
Asmaa A. K. \\ Animal and Fish Production Department, Faculty of Agriculture Saba Basha, \\ Alexandria University, Egypt. \\ Corresponding author: dr_khaled@alexu.edu.eg., aim19806150@gmail.com
}

\section{ARTICLE INFO \\ Article History: \\ Received: Feb. 26, 2019 \\ Accepted:April 18, 2019 \\ Online: April 28, 2019}

Keywords:

O. niloticus

O. aureus

T. zillii

organophosphorus pesticides

biomarker

Antioxidant activity

Glutathione S-

transferase (GST)

\section{ABSTRACT}

Three tilapia species; Oreochromis niloticus, Oreochromis aureus and Tilapia zillii were evaluated as biomarkers for five different organophosphorus pesticides (Diazenon, Lindan, Parathion, Malathion and Chlorpyrifos) at Lake Edku, Egypt. O. niloticus reflected highest accumulated pesticides comparing with $T$. zillii, which reflected lowest accumulation levels of Diazenon, Lindan, Parathion, Malathion and Chlorpyrifos respectively. O. niloticus, O. aureus and T. zillii showed varied antioxidant activity patterns corresponding with pesticide accumulation levels. O. niloticus was superior for Superoxide dismutase activity comparing with O.aureus and $T$. zillii, which reflected lower level respectively. Moreover, T. zillii reflected the lowest Catalase activity comparing with $O$. aureus that showed the highest activity. $O$. niloticus showed high glutathione Peroxidase activity comparing with $O$. aureus and $T$. zillii. Glutathione reductase reflected distinguishable variation among $O$. niloticus, $O$. aureus, and T. zillii. Glutathione - S-transferase enzyme activity was decreased for $T$. zillii comparing with O.niloticus and O.aureus. As protein fraction, Glutathione S-transferase (GST) was expressed as one single band with different protein content. Glutathione S-transferase (GST) gene sequence of $T$. zillii reflected the highest genetic similarity $(92.81 \%)$ with GST reference sequence. The lowest genetic similarity for GST gene sequence remarked (75.29\%) O. niloticus. O. aureus showed moderate genetic similarity $(87.11 \%)$ comparing with the reference gene sequence. It could be concluded that, significant correlation was detected among different organophosphorus pesticides accumulation and activity levels. Protein content and sequencing of many antioxidant enzymes indicated promising potential of employing three Tilapia species $O$. niloticus, O. aureus and T. zillii as biomarkers.

\section{INTRODUCTION}

Tilapias consider the main source of fish consumers in Africa and the Middle East. 40-50 nominal species compose Cichlidae family have been introduced to tropical and subtropical countries around the world to increase protein content (BoYoung et al. 2005). In Egypt, fish could be considered an alternative food source to capture fisheries to cover the growing demand for animal protein resources to feed 
Egypt's population. Thus, Production has increased from about 92.5 thousand tonnes in 1971 to more than 1097,544 tin 2013 (Soliman and Yacout 2016).

Recently, extent of the use of pesticides and their mode of application including their abuse especially in agriculture has been of much concern to environmental scientists. Wide spectrums of pesticides have been applied in Egypt for agricultural and public health fields. Mixing River Nile or lakes with OPs pesticides cause to discharge drainage water of pesticides treated land. Among insecticides classes, vertebrates consider the most sensitive for OPs pesticides toxicity (Chambers et al. 2001). In Egypt, many severe symptoms especially liver and kidney diseases have a dramatic increase due to unreliable use of pesticides during the last 20 years in Egypt. Furthermore, Egypt considers the fourth largest pesticides importer among developing countries (Yamashita et al. 2000). Pesticides reach aquatic ecosystem via many ways like direct application, missing spray drift, also leaking from manufacturer factories. Contamination of water sources which containing fish and other aquatic organisms consider the major concern in the light of accumulation Pesticides residuals in of aquatic organism tissues and with time (Jiries et al., 2002). Edku Lake considers the focus of attention for environmental biologist as a result of highly concentrations of heavy metals including Iron, Zinc, Copper, Manganese, Cadmium and Lead (Fe, $\mathrm{Zn}, \mathrm{Cu}, \mathrm{Mn}, \mathrm{Cd}$ and $\mathrm{Pb}$ ) (Saeed et al., 2008, 2011 and 2013).

Oxidative process plays a key role in the metabolic responses to many xenobiotics, such as chemicals, pesticides and heavy metal which responsible for inducing Reactive Oxygen Species (ROS) and alterations in the antioxidant system (Nishida 2011). Antioxidant enzymes over expression, DNA macro and micro damages, protein oxidative and lipid peroxidation products consider basic symptoms for to vigor exposer to pesticides as oxidative stress ( $\mathrm{Li}$ et al., 2007). Super oxide dismutase (SOD), catalase (CAT), glutathione peroxidase (GPx), glutathione (GSH), glutathione reductase (GR) and lipid peroxidase (LPO) classified as major antioxidant enzymes (Price et al., 1990).

Glutathione S-transferases (EC 2.5.1.18, GSTs) belong to super family of multi-functional dimeric enzymes with roles in Phase-II detoxification and expressed in almost every species (Sheehan et al. 2001). Enzymic glutathione conjugation, glutathione-dependent peroxidase activity or isomerization reactions are main mechanisms for neutralize a broad range of xenobiotics and endogenous metabolic via Glutathione S-transferases (Hayes et al. 2005; Bamidele et al. 2012). Also, GSTs catalyze the conjugation of endogenous substrates, including cholesterol, prostaglandins and leukotriene as an addition detoxification mechanism (Sheehan et al. 2001). According to amino acid sequences similarities, Alpha, Mu, Pi, Sigma, Theta, Omega, and Zeta are main classes of mammalian cytosolic GSTs (Mannervik et al. 2005). Fish GST isoforms are expressed specifically in almost all the tissues (Rabahi et al., 1999; Thyagaraju et al., 2005). In some fish species, gender differences play an important role for detoxification via GST activities as directly reflect the metabolic disturbances (Carvalho-Neta and Abreu-Silva, 2013). Additionally, using Tilapia as biomarker for pesticides contamination was mentioned in many studies (Ibrahim et al., 2014). They indicated that, exposure Nile Tilapia (Oreochromis Niloticus) to $0.3 \mathrm{and} 0.8 \mathrm{mg} / \mathrm{l}$ of chlorpyrifos for $24 \mathrm{~h}$ induced significant decreasing in metabolites parameters such as total lipid, AChE, T3, Na + and $\mathrm{Cl}$-. By contrary, cholesterol, cortisol, T4 andK + revealed marked elevation during the acute period when compared to control value whereas total protein was fluctuated during acute exposure. 
The purpose of this study was to evaluate O.niloticus, O.aureus and T.zillii capability as biomarkers for five organophosphorus pesticides (Diazenon, Lindan, Parathion, Malathion and Chlorpyrifos) at Lake Edku, Egypt. To achieve this goal, antioxidant enzyme activities and Glutathione S-transferase (GST) on gene sequence and protein expression levels were employed as effective evaluation tool.

\section{MATERIALS AND METHODS}

\section{Fish Samples:}

In this investigation, three Tilapia species O.niloticus, O.aureus and T.zillii were represented with one hundred individuals and collected with nets from Edku Lake (E"2'18 30 N"52'19³1) from summer 201` to spring 2018 (Figure 1). All samples were collected and transported immediately to the laboratory in an ice box with ice and stored at $4{ }^{\circ} \mathrm{C}$ in a refrigerator for two days before extensive analysis.

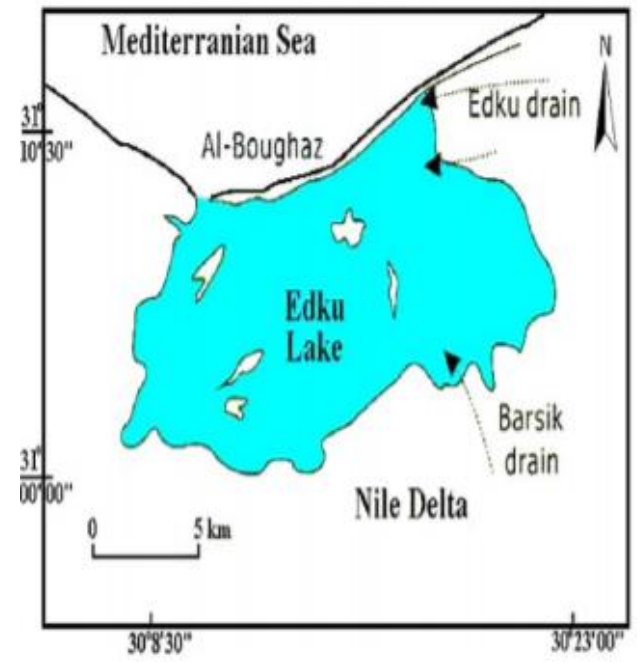

Fig. 1: Location of the Edku Lake.

\section{Organophosphorus pesticides standards and reagents}

Pesticide standards of Lindan, Diazenon, Parathion, Malathion and Chlorpyrifos were purchased from Sigma (Poole, UK). Firstly, the standard pesticide solution was prepared individually by dissolving $10 \mathrm{mg}$ of each compound in $10 \mathrm{~mL}$ hexane and stored in amber bottles. Secondly, concentrations of $100 \mathrm{mg} / \mathrm{L}$ of each individual standard stock solution were mixed. Through diluting $100 \mathrm{mg} / \mathrm{L}$ of the mixed standard solution, series of calibration standards were prepared to produce a final concentration of $0.1,0.2,0.5,1.0,2.0 \mathrm{mg} / \mathrm{L}$ in hexane and stored at 4 ${ }^{\circ} \mathrm{C}$ till usage. Acetone, n-hexane, methylene chloride, toluene, and acetonitrile were applied as solvents were categorized as (HPLC) grade and supplied by Sigma, USA.

\section{Sample extraction}

The extraction and clean-up technique employed in this work was according to Chen et al. (2009). Fifteen grams of each fish muscle samples vortexes for $1 \mathrm{~min}$ with $3.0 \mathrm{~mL}$ of double distilled water. Then, $20 \mathrm{~mL}$ of acetonitrile was added as an extraction solvent. Additionally, $5 \mathrm{~g}$ sodium chloride was added to the mixture and vortexes for another $2 \mathrm{~min}$ and centrifuged for $5 \mathrm{~min}$ at $4000 \mathrm{rpm}$. To precipitated total lipids as pale yellow, $10 \mathrm{~mL}$ of the extraction solution was stored in 100 $\mathrm{mL}$ freezed flask at $-24{ }^{\circ} \mathrm{C}$ for $20 \mathrm{~min}$. then, precipitated lipid was dissolved in 10 $\mathrm{mL}$ of acetonitrile and finally concentrated to $1 \mathrm{~mL}$ by rotary evaporation to follow 
SPE procedure. NH2 cartridge supplemented with anhydrous sodium sulfate was applied for sample Clean-up according to Yahia and ELsharkawy (2013).

\section{GC $\backslash$ MS analysis for Malathion}

Different organophosphorus pesticides were detected for Oreochromis niloticus muscles samples through Agilent 7890 instrument equipped with 5975 insertion source mass detection system (Agilent Technologies, USA). Ten grams of each fish muscles were extracted and cleaned up according to Chen et al. (2009). After that and before sample application, anhydrous sodium sulfate was placed on top of NH2 cartridge according to Yahia and ELSharawy (2013).

\section{Antioxidant enzyme assays}

Six Antioxidant enzymes were evaluated as Malathion indicators. One gram of Oreochromis niloticus muscles which collected from different five locations from Edku Lake was homogenized through Kinematica Polytron ${ }^{\mathrm{TM}}$ PT2100 Benchtop homogenizer for $5 \mathrm{~min}$ in ice cold $0.1 \mathrm{M}$ Tris- $\mathrm{HCl}$ buffer solution. Then, centrifuges at $6000 \mathrm{rpm}$ for $20 \mathrm{~min}$. finally, supernatant was removed and stored for $20^{\circ} \mathrm{C}$ for antioxidant enzyme assays. Superoxide dismutase, Catalase, glutathione peroxidase, Glutathione reductase, Glutathione a were used as different pesticides biomarker according to Kakkar et al. (1984), Maehly and Chance (1954), Lawrence and Burk (1976), David and Richard (1983), Patterson and Lazarow (1995) respectively.

\section{Purification Glutathione S-transferases (GSTs) using affinity chromatography} GST enzyme was coupled to Epoxy-activated Sepharose 6B according to Simons and Jagt (1977). 5 grams of each O. niloticus, O. aureus, and T. zillii muscles were homogenized in 50\% (w/v) 25 mMTris-HCl buffer, $\mathrm{pH} 8.0$ containing $1 \mathrm{mM}$ EDTA and $1 \mathrm{mM}$ DTT. Then, homogenates were centrifuges at $10,000 \mathrm{xg}$ for 15 min. crude extracts was obtained via filtration and kept at $-20^{\circ} \mathrm{C}$ to purify GST using affinity chromatography. $15 \mathrm{~mL}$ of GSH-Sepharose matrix was mixed for 30 min at $4{ }^{\circ} \mathrm{C}$ with shaking separately with Crude extracts. Then, packed to a column $(15 \times 1 \mathrm{~cm}$ i.d.) and eluted with $50 \mathrm{mMTris}-\mathrm{HCl}$ buffer, $\mathrm{pH} 8.0$ containing 10 $\mathrm{mM} \mathrm{GSH}$ at a flow rate of $1 \mathrm{~mL} / \mathrm{min}$.

\section{GST electrophoretic patterns}

Purified Glutathione S-transferase (GST) from O. niloticus, O. aureus and $T$. zillii were examined by $7 \%$ polyacrylamide gel electrophoresis (PAGE) followed by staining for protein using Coomassie brilliant blue according to Laemmli (1970). A single band corresponding to a molecular mass of $27.5 \mathrm{kDa}$ was detected and remarked GST.

\section{Glutathione S-transferase gene amplification and sequencing}

Genetic variation for GST DNA sequences was applied as bioindicator for pesticides accuilation. Thus, total RNA were extracted for $O$. niloticus, $O$. aureus and T. zillii muscles which exposer to different organophosphorus pesticides through GeneJET RNA Purification Kit, (\#K0731, Thermo Scientific). Nanodrop ND-1000 spectrophotometer (Nano Drop Products, Thermo Fisher Scientific, Schwerte, Germany) was applied to check the quantity and purity of extracted RNA. High-Capacity cDNA Reverse Transcription Kit (Thermo Fisher Scientific, USA) was applied to convert purified RNA to complementary DNA from purified. Complementary DNA (cDNA) products were stored at $20^{\circ} \mathrm{C}$ for PCR. GST specific primer For: ATG TCA AGA CTG AAG CTA TAC TTT G and Rev: TTA AAT CTT GGA TGC CAG GAA GTG Rhee $e t \quad a l$, (2007) were applied to amplify Glutathione S-transferase gene. The PCR products with 480 bp were determined with $1.5 \%$ agarose gel electrophoresis. Gel docum- 
entation system (Geldoc-it, UVP, England), was applied for data analysis using Totallab analysis software, ww.totallab.com, (Ver.1.0.1). Specific GST gene fragments were eluted from agarose gel through E.Z.N.A.® ${ }^{\circledR}$ Gel Extraction Kit (omega BioTEK, USA). Sequence analysis was employed using the ABI PRISM® 3100 Genetic Analyzer (Micron-Corp. Korea). Aligned sequences were analyzed on NCBI website (http://www.ncbi.nlm.nih.gov/website) using BLAST to confirm their identity. Phylogenetic tree constructed based on Glutathione S-transferase gene sequence homology, and birds were computed by Pairwise Distance method using ClusteralW software analysis (www.ClusteralW.com).

\section{Statistical Analysis}

Our obtaining findings of antioxidant enzyme quantifications from five locations were statistically analyzed to evaluate significant differences by using independent t-test sample (SPSS version 7.0.1 copyright SPSS INC1997).

\section{RESULTS}

This investigation was carried out to evaluate employment O.niloticus, O.aureus and T.zillii as a biomarker for organophosphorus pesticides at Edku Lake, Egypt. Different accumulation levels for organophosphorus pesticides were detected for O.niloticus, O.aureus and T.zillii. As shown by Table (1) and Figure (2), for five organophosphorus pesticides, O.niloticus accumulated highest pesticides levels $(2.81 \pm 0.25,1.25 \pm 0.21,7.15 \pm 0.85,0.51 \pm 0.11$ and $0.37 \pm 0.25)$ comparing with T.zillii which reflected lowest accumulation levels $(1.98 \pm 0.45,0.26 \pm 0.62,4.55 \pm 0.55$, $0.21 \pm 0.36$ and $0.14 \pm 0.19$ ) for Diazenon, Lindan, Parathion, Malathion and Chlorpyrifos respectively. Additionally, O.aureus showed moderate accumulation level with $2.14 \pm 0.74,0.65 \pm 0.68,5.25 \pm 0.280 .35 \pm 0.17$ and $0.28 \pm 0.65$ for Diazenon, Lindan, Parathion, Malathion and Chlorpyrifos respectively.

Table 1: Average concentration $(\mu \mathrm{g} / \mathrm{Kg})$ of the different types of pesticide residues in the examined tilapia samples $(n=10$ pooled samples with five fish each). In area

\begin{tabular}{lccccc}
\hline \multirow{2}{*}{ Tilapia species } & \multicolumn{5}{c}{ Average concentration of Pesticides } \\
\cline { 2 - 6 } & Diazenon & Lindan & Parathion & Malathion & Chlorpyrifos \\
\hline O. aureus & $2.14 \pm 0.74$ & $0.65 \pm 0.68$ & $5.25 \pm 0.28$ & $0.35 \pm 0.17$ & $0.28 \pm 0.65$ \\
O. niloticus & $2.81 \pm 0.25$ & $1.25 \pm 0.21$ & $7.15 \pm 0.85$ & $0.51 \pm 0.11$ & $0.37 \pm 0.25$ \\
T. zillii & $1.98 \pm 0.45$ & $0.26 \pm 0.62$ & $4.55 \pm 0.55$ & $0.21 \pm 0.36$ & $0.14 \pm 0.19$ \\
\hline
\end{tabular}

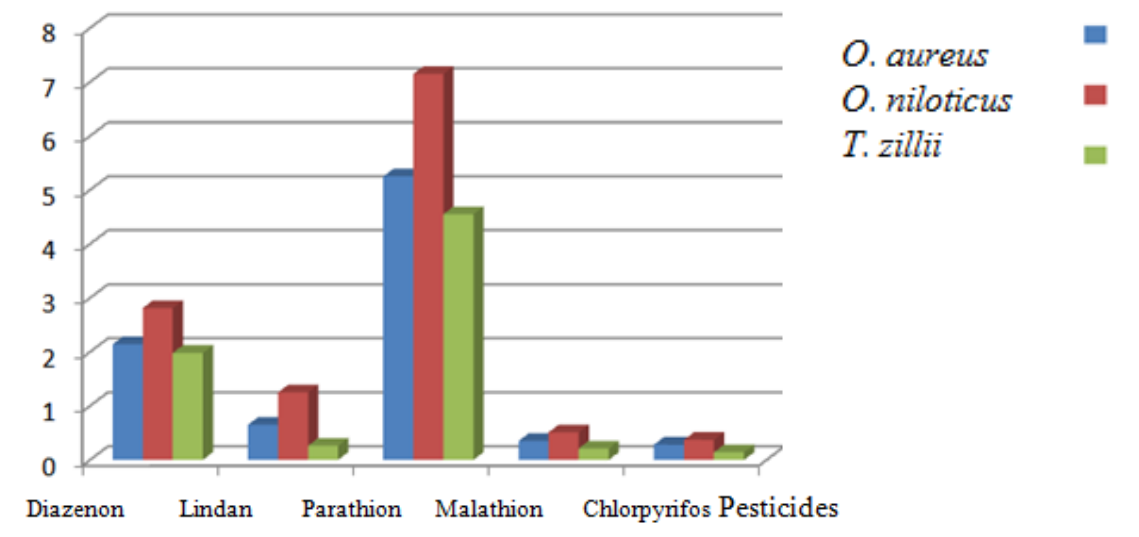

Fig. 2: Average concentration $(\mu \mathrm{g} / \mathrm{Kg})$ of five pesticide residues for, and Where: 


\section{Evaluation of antioxidant enzyme activities}

As shown by Table (2), as a direct response for different accumulation levels of organophosphorus pesticides, antioxidant enzyme activities reflected significant variation among three Tilapia species. Generally, O. niloticus expressed highly significant antioxidant enzyme activities which consequential descendingly for $O$. aureus and $T$. zillii respectively. For Superoxide dismutase, O. niloticus was superior for activity with $151.6 \pm 10.5$ comparing with $O$. aureus and $T$. zillii which reflected $137.5 \pm 6.8$ and $86.6 \pm 9.4$ respectively. Also, T.zillii reflected lowest Catalase activity with $92.5 \pm 58.6$ comparing with $O$. aureus which showed the highest activity (191.5 \pm 96.2$)$. O. niloticus showed high glutathione Peroxidase activity (1.84 \pm 0.52 ) comparing with $O$. aureus and $T$. zillii which reflected $1.77 \pm 0.61$ and $0.87 \pm 0.17$ respectively. Glutathione reductase reflected distinguish variation among $O$. niloticus, $O$. aureus and T.zillii which showed $1.78 \pm 0.12,1.65 \pm 0.08$ and $1.12 \pm 0.14$. finally, significant dramatic decrease was detected for Glutathione -Stransferase enzyme activity for T.zillii $(0.34 \pm 0.34)$ comparing with $O$. niloticus and O. aureus $(0.81 \pm 0.08$ and $0.75 \pm 0.14$ respectively).

Table 2: Antioxidant enzyme activities $(\mu \mathrm{M} / \mathrm{min} / \mathrm{g} /$ wet weight tissue) for tilapia species

\begin{tabular}{lccccc}
$\begin{array}{c}\text { Tilapia } \\
\text { Species }\end{array}$ & $\begin{array}{c}\text { Superoxide } \\
\text { dismutase }\end{array}$ & Catalase & $\begin{array}{c}\text { glutathione } \\
\text { Peroxidase }\end{array}$ & $\begin{array}{c}\text { Glutathione } \\
\text { reductase }\end{array}$ & $\begin{array}{c}\text { Glutathione - } \\
\text { S-transferase }\end{array}$ \\
\hline O. aureus & $137.5 \pm$ & $184.2 \pm$ & $1.77 \pm$ & $1.65 \pm$ & $0.75 \pm$ \\
& 71 & 22.5 & 0.84 & 0.07 & 0.11 \\
\hline O. niloticus & $151.6 \pm$ & $191.5 \pm$ & $1.84 \pm$ & $1.78 \pm$ & $0.81 \pm$ \\
& 12.5 & 39.2 & 0.22 & 0.23 & 0.10 \\
\hline T. zillii & $86.6 \pm$ & $92.5 \pm$ & $0.87 \pm$ & $1.12 \pm$ & $0.34 \pm$ \\
& 3.5 & 14.3 & 0.17 & 0.19 & 0.24 \\
\hline
\end{tabular}

\section{Purification GST Polyacrylamide gel electrophoresis}

Glutathione S-transferase (GST) of $O$. niloticus, O. aureus and T. zillii were purified by affinity chromatography. Then, fractionated via $7 \%$ polyacrlyamide gel electro-phoresis (PAGE) to detect and quantify protein content. Glutathione Stransferase (GST) was expressed as one single band with different protein content for O. niloticus, O. aureus and T. zillii as tested by 7\% PAGE (Fig.3). O. niloticus expressed Glutathione S-transferase (GST) as 1.5 and 4.7 folds than $O$. aureus and $T$. zillii respectively.

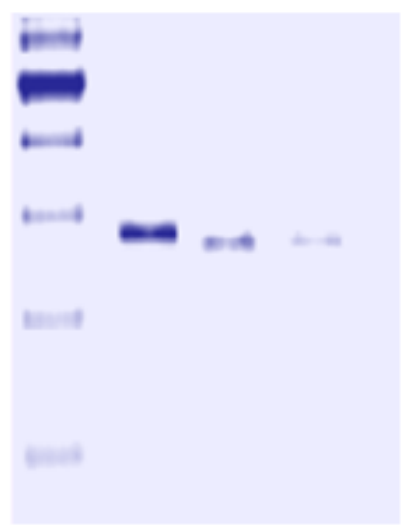

(A)

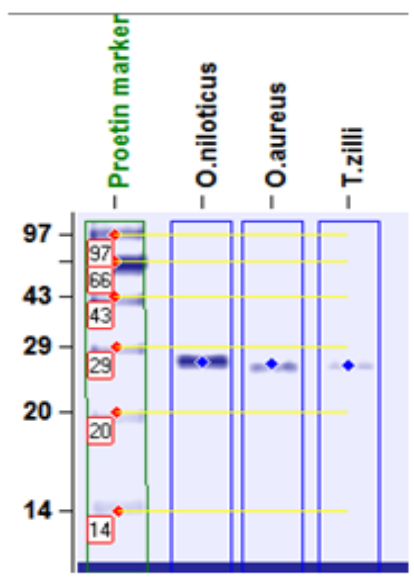

(B)

\begin{tabular}{|c|c|c|c|r|r|}
\hline \multicolumn{2}{|c|}{ O.niloticus (2) } & \multicolumn{2}{c|}{ O.aureus (3) } & \multicolumn{2}{c|}{ T.zilli (4) } \\
\hline Lane \% & MW & Lane \% & MW & Lane \% & MW \\
\hline 3.00 & 26.325 & 1.90 & 26.103 & 0.63 & 25.884 \\
\hline
\end{tabular}

Fig. 3: Polyacrylamide gel electrophoresis for affinity purified GST of the three tilapia species 


\section{GST Gene sequencing analysis}

Comparing with reference GST gene sequence, O. niloticus, O. aureus and T. zillii GST gene amplification and sequencing were employed as molecular biomarker to evaluate direct different OP influence through comparing with reference GST gene (Oreochromis niloticus glutathione S-transferase (LOC100534425), mRNA NCBI Reference Sequence: NM_001279634.1). As shown by Figure (4), GST amplicons were obtained for $O$. aureus, $O$. niloticus and T.zillii with remarkable fragment length ( 480bp). Then, GST gene were purified and sequenced for each species and different GST gene sequences identity $\%$ were recorded. $O$. niloticus, $T$. zillii and $O$. aureus GST gene sequences identified as Oreochromis niloticus glutathione Stransferase (LOC100534425), mRNA NCBI Reference Sequence: NM_001279634.1 with $89.89 \%, 100 \%$ and 94.02 of identity \% respectively (Figure 5A, B and C).

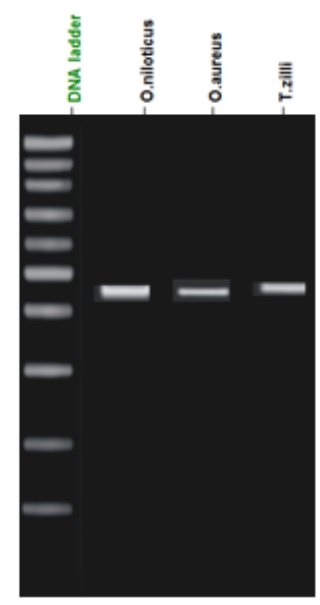

(A)

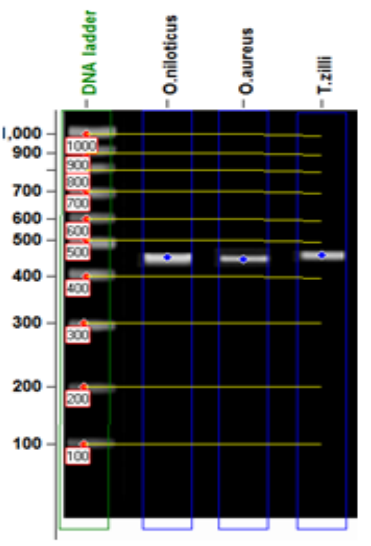

(B)

Fig. 4: Glutathione S-transferases (GST) amplicons (A) and computerized fragments length calculation (B) for O.aureus, O.niloticus and T.zillii.

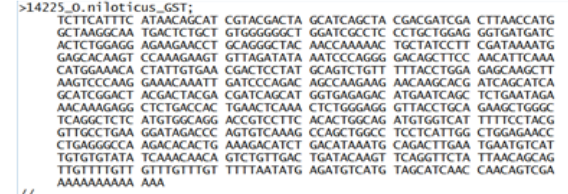

(A)

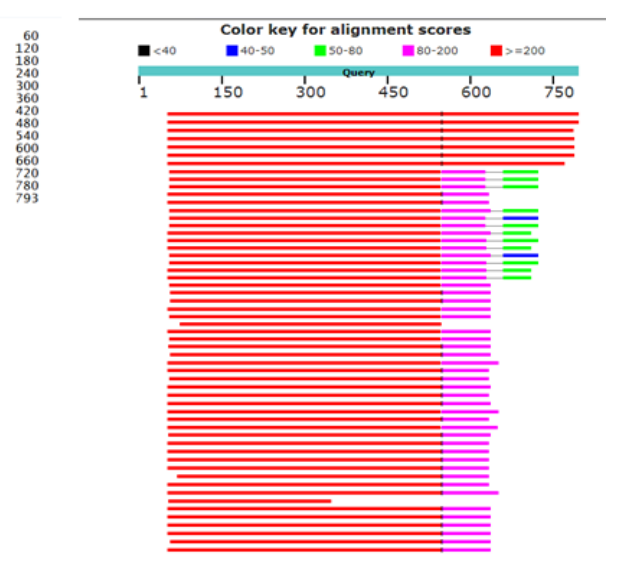

(B)

Fig. 5A: O. niloticus Glutathione S-transferases (GST) sequence (A) and alignment data (B). 


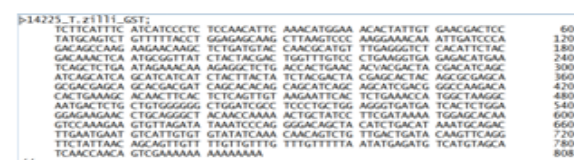

(A)

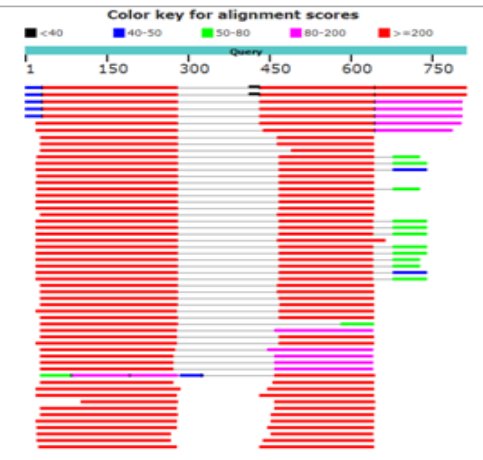

(B)

Fig. 5B: T.zillii Glutathione S-transferases (GST) sequence (A) and alignment data (B).

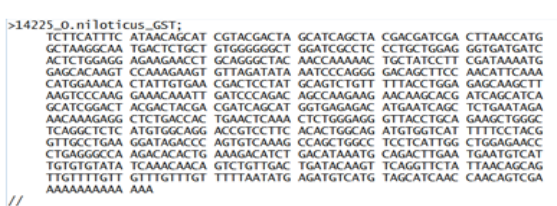

(A)

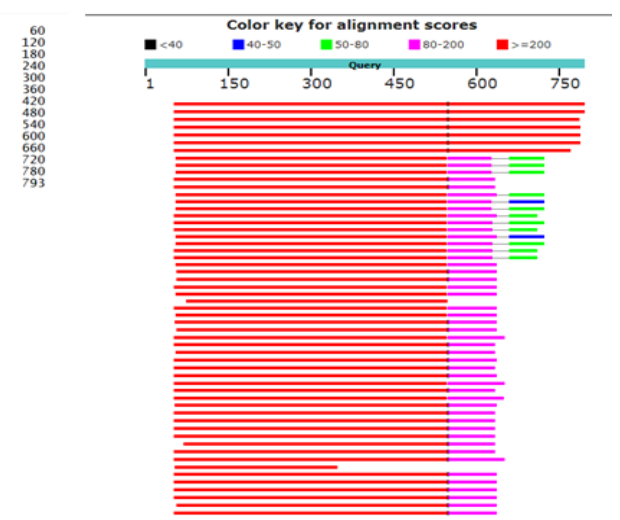

(B)

Fig. 5C: O.aureus Glutathione S-transferases (GST) sequence (A) and alignment data (B).

To estimate genetic similarity among GST gene sequences of $O$. niloticus, $O$. aureus and T. zillii and reference GST gene (Oreochromis niloticus glutathione Stransferase (LOC100534425), phyllogenetic tree was constructed (Figure 6). Corresponding with GST gene sequence data, as shown by Table (3) T.zillii GST gene sequence reflected the higest genetic similarity (92.81\%) with GST reference sequence. Also, lowest genetic similarity for GST gene sequecen remarked (75.29\%) O. niloticus. O. aureus showed moderate genetic similarity $(87.11 \%)$ comparing with reference gene sequence.

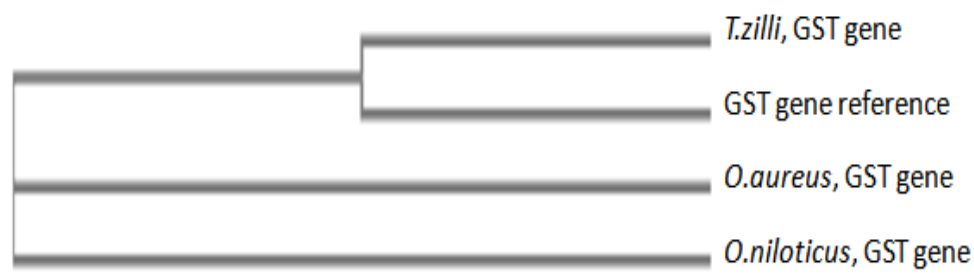

Fig. 6: phyllogenetic tree for O. niloticus, O. aureus and T. zillii based on GST gene sequences. 
Table 3: Percent Identity Matrix for O.niloticus, O.aureus and T.zillii based on GST gene sequences.

\begin{tabular}{lcccc}
\hline \multicolumn{1}{c}{ Tilapia species } & O. niloticus & O. aureus & T. zillii & Gst reference gene \\
\hline O. niloticus & 100 & 87.58 & 71.84 & 75.29 \\
O. aureus & 87.58 & 100 & 68.05 & 87.11 \\
$\boldsymbol{T}$. zillii & 71.84 & 68.05 & 100 & 92.81 \\
Gst reference gene & 75.29 & 87.11 & 92.81 & 100 \\
\hline
\end{tabular}

\section{DISCUSSION}

Our findings provided significant addition for Egyptian ecology though employment different biochemical and molecular markers as biomarker for accumulated pesticides of Some Egyptian Tilapia Species. More light was added to our findings for applied Tilapia sp. as a biosensor for pesticides stresses by Grillitsch et al. (1999). They indicated that, Tilapia guineensis reflected behavioral responses to acute and sublethal toxicity of pesticides. Furthermore, in accordance with our results for direct response of organophosphorus pesticides different accumulation levels, Chindah et al. (2001) noted that aquatic organisms (shell and fin fishes) will be vulnerable to respiratory tract damage and other organs of the body.

Our investigation for assessment pesticides toxicity referring to aquatic biota, especially fish was employed in many previous studies (Kumar et al., 2015). Employment glutathione S-transferase (GST) as biomarker for environmental marine contamination was supported by Pathiratne et al., (2009). They indicated that GST activities in fish from highly contaminated Bolgoda Lake were induced 4.2-16.6 folds compared with the control fish. In accordance with our findings for using many biochemical parameters as biomarker for pesticides accumulation, additional enzymes such as, glucose-6-phosphate dehydrogenase (G6PDH) and lactate dehydrogenase (LDH) were applied as biomarker for pollutants prediction in Nile tilapia tissues (Osman 2012).

In accordance with our represented data for using antioxidant activity as biomarker for pesticides accumulation, Jiminez and Stegeman, (1990) showed that, activity of antioxidant may be increased or inhibited under chemical stress depending on the intensity and duration of stress applied as well as susceptibility of exposure species. Diffraction for SOD activity among O. niloticus, O. aureus and T.zillii under organophosphorus pesticides In consistence with Vander Oost et al., (2003) findings which clear that, SOD is responsible for the removal of hydrogen peroxide which is metabolized to oxygen and water. Our presented findings to evaluate Superoxide dismutase, Catalase, glutathione peroxidase, Glutathione reductase, Glutathione as pesticides biomarkers was in accordance of many studies which recorded the same antioxidant enzymes within the same range for other fresh water fishes (Oruce and Usta, 2007; Talas et al., 2008; Metwaly 2009; Wenju et al., 2009 and Gad and Yacoub 2009). Similar results for employment antioxidant enzymes as contaminant indicators have been monitored in gilthead sea bream (Sparus aurata) and Carassius auratus exposed to polyaromatic hydrocarbons as phenanthrene (Sun et al., 2006 and Correia et al., 2007). Varied values of GST in the . O.niloticus, T.zillii and O.aureus tissues were found to be within the same range of other freshwater fishes (Oruce and Usta 2007; Talas et al., 2008; Wenju et al., 2009 and Gad 2009).

To get better understanding between Glutathione S-transferase (GST) and pesticide accumulations for three Tilapia species, O. niloticus, O. aureus and T.zillii, Glutathione S-transferase (GST) was purified and fractionated and recorded as one single band of specific molecular weight $(27 \mathrm{KDa})$ with different protein expression 
content. Superior Glutathione S-transferase (GST) protein expression of $O$. niloticus comparing with $O$. aureus and $T$. zillii could be explained in the light of highly accumulation levels for different organophosphorus pesticides under study corresponding with dramatic increase of antioxidant activity. Our presented findings are in agreement with specified Glutathione S-transferase (GST) molecular weights which mentioned by the major isoforms of GST from different fish species expressed as ranging molecular mass from 22.4 to $26.9 \mathrm{KDa}$ (Nova-Valinas et al. 2002; Hamed et al. 2004). Furthermore, more support was added to our findings Huang et al. (2008). They detect similar GST protein pattern. Also, condensed subunits of molecular mass equal $24.8 \mathrm{kDa}$ was fractionated for predominant GST for salmon fish livers.

In the present study, Glutathione S-transferase (GST) gene were amplified, eluted, sequenced and alignments for Tilapia species, $O$. niloticus, $O$. aureus and $T$. zillii. Then, genetic similarity and phyllogenetic tree was constructed comparing with GST reference gene sequence. Glutathione S-transferase (GST) gene sequence finding added more light to clear resistance and adaptation mechanism of organophosphorus pesticides for Tilapia species.

\section{CONCLUSION}

This investigation carried out to evaluate employment $O$. niloticus, $O$. aureus and T. zillii as biomarker for different organophosphorus pesticides at Edku lake, Egypt. O. niloticus, $O$. aureus and T.zillii reflected varied accumulation levels for Diazenon, Lindan, Parathion, Malathion and Chlorpyrifos. Antioxidant activity and Glutathione S-transferase gene sequences and protein expression levels clear better understanding of pesticides accumulation molecular base, resistance and adaptation for $O$. niloticus, $O$. aureus and T.zillii. our previous data could be concluded as potential probability for applying $O$. niloticus, $O$. aureus and $T$. zillii as biomarker for organophosphorus pesticides accumulation.

\section{REFERENCES}

Abdel-Aziz, M. S.; Ghareeb, M. A., Saad A. M.; Refahy, L. A.; Hamed, A. A. (2018). Chromatographic isolation and structural elucidation of secondary metabolites from the soil-inhabiting fungus Aspergillus fumigatus 3T-EGY. Acta Chromatogr., 30: 243-249.

Abdel-Hady, H.; Abdel-Wareth, M.T.A.; El-Wakil, E.A. and Helmy, E.A. (2016). Identification and evaluation of antimicrobial and cytotoxic activities of Penicillium islandicum and Aspergillus tamarii ethyl acetate extracts. World J. Pharm. Pharm. Sci., 5: 2021-2039.

Agoramoorthy, G.; Chandrasekaran, M.; Venkatesalu, V. and Hsu, M. J. (2007) Antibacterial and antifungal activities of fatty acid methyl esters of the blindyour-eye mangrove from India. Braz. J. Microbiol., 38: 739-42.

Bauer, A.W.; Kirby, W.M.; Sherris, J.C. and Turck, M. (1966) Antibiotic susceptibility testing by a standardized single disk method. Am. J. Clin. Pathol., 45: 493-496.

Boik, J. (2001). Natural Compounds in Cancer Therapy. Oregon Medical Press, Minnesota, USA.

Bolognesi, C. and Cirillo, S. (2014). Genotoxicity biomarkers in aquatic bioindicators. Curr. Zool., 60: 273-284. 
Boucias, D.G. and Pendland, J.C. (1998). Principles of Insect Pathology, Kluwer Academic Publishers, Boston, USA.

Chandrasekaran, M.; Kannathasan, K. and Venkatesalu, V. (2008). Antimicrobial activity of fatty acid methyl esters of some members of Chenopodiaceae. Zeitschrift für Naturforschung C, 63: 331-336.

Chibale, K.; Visser, M.; Schalkwyk, D.V.; Smith, P.J.; Saravanamuthu, A. and Fairlamb, A.H. (2003). Exploring the potential of xanthene derivatives as trypanothione reductase inhibitors and chloroquine potentiating agents. Tetrahedron, 59: 2289-2296.

Demain, A.L. (1999). Pharmaceutically active secondary metabolites of microorganisms. Appl. Microbiol. Biotechnol., 52: 455-463.

Doll, R. and Peto, R. (2003). Malignant diseases. In: "Text Book of Medicine.", fourth ed. Oxford University Press, USA, pp. 483-484.

Elaasser, M.M.; Abdel-Aziz, M.M. and El-Kassas, R.A. (2011). Antioxidant, antimicrobial, antiviral and antitumor activities of pyranone derivative obtained from Aspergillus candidus. J. Microbiol. Biotech. Res., 1: 5-17.

EPA US (Environmental Protection Agency (2005). Paecilomyces lilacinus strain 251; exemption from the requirement of a tolerance. United States Federal Register, 70: 19278-19283.

Ezz, N.A.; Hameida, I.A.; El-Shabrawy, H.A.; El-Sahn, O.M.N.I. and Helmy, I.E. (2008). Evaluation of the entomopathogenic fungus Beauveria bassiana (Balsamo) as a biocontrol agent against the soft scale insect, Saissetia coffeae (Walker) (Homotera:Coccidae). Egypt J. Biol. Pest Cont., 18: 75-80.

Fabelico, F.L. (2015). The phytochemical and antimicrobial properties of entomopathogenic fungi in Nueva Vizcaya, Philippines. Asia Pac. J. Multidisciplinary Res., 3: 126-133.

Fairbairn, D.W., Olive, P.L. and O’Neill, K.L. (1995). The comet assay: A comprehensive review. Mutat. Res., 339: 37-59.

Francardi, V.; Benvenuti, C.; Barzanti, G.P. and Roversi, F. (2015). Metarhizium anisopliae biopesticides and fungus isolates: Control efficacy against Rhynchophorus ferrugineus (Olivier) (Coleoptera: Dryophthoridae) on different contamination substrata. J. Zool., 98: 25-29.

Ghareeb, M.A.; Mohamed, T.; Saad, A.M.; Refahy, L.A.; Sobeh, M.; Wink M, et al. (2018a). HPLC-DAD-ESI-MS/MS analysis of fruits from Firmiana simplex (L.) and evaluation of their antioxidant and antigenotoxic properties. J. Pharm. Pharmacol., 70:133-142.

Ghareeb, M.; Saad, A.; Ahmed, W.; Refahy, L. and Nasr S. (2018b). HPLC-DAD-ESI-MS/MS characterization of bioactive secondary metabolites from Strelitzia nicolai leaf extracts and their antioxidant and anticancer activities in vitro. Pharmacogn. Res., 10: 368-378.

Gulwani, N.; Shukla, H. and Sandhu,S. S. (2015). Screening the antibacterial potential of Paecilomyces fumosoroseus against some pathogenic bacteria. Open J. Adv. Drug Delivery, 3: 24-31.

Haggag, E.G.; Kamal, A.M.; Abdelhady, M.I.; El-Sayed, M.M.; El-Wakil, E.A. and Abd-El-hamed, S.S. (2011). Antioxidant and cytotoxic activity of polyphenolic compounds isolated from the leaves of Leucenia leucocephala. Pharm. Biol., 49: 1103-1113.

Hamed, S.S.; Abdelmeguied, N.E.; Essawy, A.E.; Radwan, M.A. and Hegazy, A.E. (2007). Histological and ultrastructural changes induced by two 
carbamate molluscicides on the digestive gland of Eobania vermiculata. J. Biol. Sci., 7:1017-1037.

Hepsibah, A. H. and Jothi, G. J. (2017). A comparative study on the effect of solvents on the phytochemical profile and biological potential of Ormocarpum cochinchichinese Auct. Non (Lour.) Merrill. Int. J. Pharm. Pharm. Sci., 9: 6772.

Ibrahim, A.M.; Sayed, S.S. and Shalash, I. R. (2018). Toxicological assessment of lambda-cyhalothrin and acetamiprid insecticides formulated mixture on hatchability rate, histological aspects, and protein electrophoretic pattern of Biomphalaria alexandrina (Ehrenberg, 1831) snails. Environ. Sci. Pollut. Res., 25: 32582-32590.

Ibrahim, A.M.; Ibrahim, W.L.F and Abou-Aouf , A.H. (2006). Ultrastructural study of the effect of a plant molluscicide (Solanum elaegnifolium) on the digestive and hermaphrodite glands of Biomphalaria alexandrina. Egypt. J. Aquat. Biol. Fish., 10:1-22.

Kershaw, M.J.; Moorhouse, E.R.; Bateman, R.; Reynolds, S.E. and Charnley, A.K. (1999). The role of destruxins in the pathogenicity of Metarhizium anisopliae for three species of insects. J. Invertebr. Pathol., 74: 213-223.

Kiewnick, S. and Sikora, R. A. (2003). Efficacy of Paecilomyces lilacinus (strain 251) for the control of root-knot nematodes. Comm. Appl. Biol. Sci., 68: 123128.

Kiewnick, S. and Sikora, R.A. (2006). Evaluation of Paecilomyces lilacinus strain 251 for the biological control of the northern root-knot nematode Meloidogyne hapla Chitwood. Nematol., 8: 69-78.

Kiran, K. and Mohan, C. M. (2018). Antioxidant and cytotoxic activity of Beauveria bassiana crude mycelia extracts against A-549 cell line. Indian J. Pharm. Sci., 80: 776-780.

Kishore, K.H.; Misra, S.; Chandra, D.R. and Prakash, K. V. (2007). Antimicrobial efficacy of secondary metabolities from Glomerella cingulata. Brazilian J. Microbiol., 38: 150-152.

Lajtner, J.; Erben, R. and Klobucar, G.I.V. (1996). Histopathological effects of Phenol on the digestive gland of Amphimelania holandri Fer. (Gastropoda, Prosobranchia). Bull. Environ. Contam. Toxicol., 57: 458-464.

Lee, S. Y.; Nakajima, I.; Ihara, F.; Kinoshita, H. and Nihira, T. (2005). Cultivation of entomopathogenic fungi for the search of antibacterial compounds. Mycopathol., 160: 321-325.

Litchfield, J.T. and Wilcoxon, F. (1949). A simplified method of evaluating doseeffect experiments. J. Pharmacol. Exp. Ther., 96: 99-113.

Ma, Q.G.; Xu, K.; Sang, Z.P.; Wei, R.R.; Liu, W.M.; Su, Y.L.; ... , Li, L.J. (2016). Alkenes with antioxidative activities from Murraya koenigii (L.) Spreng. Bioorg. Med. Chem. Lett., 26: 799-803.

Mabrouk, A. M.; Kheiralla, Z. H.; Hamed, E.R.; Youssry, A.A. and Abd El Aty, A. (2008). Production of some biologically active secondary metabolities from marine-derived fungus Varicosporina ramulosa. Malaysian J. Microbiol., 4: $14-24$

Maketon, M.; Suttichart, K. and Domhom, J. (2009). Effective control of invasive apple snail (Pomacea canaliculata Lamarck) using Paecilomyces lilacinus (Thom) Samson. Malacol., 51:181-190. 
Mohammadi, S.; Soltani, J. and Piri, K. (2016). Soilborne and invertebrate pathogenic Paecilomyces species show activity against pathogenic fungi and bacteria. J. Crop Prot., 5: 377-387.

Mohamed, S.H. and Saad, A. A. (1990). Histological studies on the hermaphrodite gland of Lymnaea caillaudi and Biomphalaria alexandrina upon infection with certain larval trematodes. Egypt. J. Histol., 13: 47-53.

Mosmann, T. (1983). Rapid colorimetric assay for cellular growth and survival: application to proliferation and cytotoxicity assays. J. Immunol. Meth., 65: 5563.

Mossalem, H.S.; Abdel-Hamid, H. and El-Shinnawy, N.A. (2013). Impact of artemether on some histological and histochemical parameters in Biomphalaria alexandrina. Afr. J. Pharm. Pharmacol., 7: 2220-2230.

Oliveria-Filho, E. C. and Paumgartten, F.J. (2000). Toxicity of Euphorbia milii latex and Niclosamide to snails and nontarget aquatic species. Ecotoxicol. Environ. Safety, 46:342-350.

Osman, G.Y.; Mohamed, A.M.; Abdel Kader, A. and Mohamed, A. A. (2013). Biological and biochemical impacts of the fungal extract of Aspergillus fumigatus on Biomphalaria alexandrina snails infected with Schistosoma mansoni. Biosci., 7: 473-485.

Osman, G.Y.; Mohamed, A.H.; Sheir, S. K., Hassab EL-Nabi, S.E. and Allam, S.A. (2014). Molluscidal activity of mirazid on Biomphalaria alexandrina snails: biological and molecular studies. Internat. J. Advan. Res., 2: 977-989.

Parine, N.R.; Pathan, A.K.; Sarayu, B.; Nishanth, V.S. and Bobbarala, V. (2010). Antibacterial efficacy of secondary metabolites from entomopathogenic fungi Beauveria Bassiana. Int. J. Chem. Anal. Sci., 1: 94-96.

Prieto, P.; Pineda, M. and Aguilar, M. (1999). Spectrophotometric quantation of antioxidant capacity through the formation of a phosphomolybdenum complex: Specific application to the determination of vitamin E. Anal. Biochem., 269: 337- 341.

Ravindran, K.; Sathishkumar, G.; Rajkuberan, C. and Sivaramakrishnan, S. (2014). Antibacterial activity of indigenous entomopathogenic fungus Metarhizium anisopliae against clinically isolated human pathogens. Int. J. Pharm. Pharmac. Sci., 6: 179-182.

Ross, C. F. (2005). Extracellular compounds having antibacterial properties produced by the entomopathogenic fungus Beauveria bassiana. $\mathrm{Ph} \mathrm{D}$, Oklahoma State Univ., pp. 700.

Saad, A.E.; Khalil, M.T.; Ragab, F.M.; Mekawey, A.A. and Abdel-Wareth, M.T. (2014). Efficacy of the fungi Aspergillus terreus and Penicillium janthinellum as biological control agents against Biomphalaria alexandrina snails. Int. J. Environ. Sci. Eng., 5: 25-37.

Sarkar, A.; Bhagat, J.; Ingole, B.S.; Rao, D.P. and Markad, V.L. (2015). Genotoxicity of cadmium chloride in the marine gastropod Nerita chamaeleon using comet assay and alkaline unwinding assay. Environ. Toxicol., 30:177187.

Shaikh, R.; Pund, M.; Dawane, A. and Iliyas, S. (2014). Evaluation of anticancer, antioxidant and possible anti-inflammatory properties of selected medicinal plants used in Indian traditional medication. J. Trad. Compl. Med., 4: 253-257.

Sharma, A.; Sharma, S. and Dalela, M. (2014). Nematicidal activity of Paecilomyces lilacinus 6029 cultured on Karanja cake medium. Microb. Pathog.,75: 16-20. 
Sheng, K.S. (2007). Current status of biopesticides, development, farmer's acceptance and utilization and future perspective in Taiwan. Extension Bull. Food and Fertilizer Technology Center 599, 20 pp.

Singh, N. P.; McCoy, M.T.; Tice, R.R. and Schneider, E.L. (1988). A simple technique for quantitation of low levels of DNA damage in individual cells. Exp. Cell Res., 175: 184-191.

Singkaravanit, S.; Kinoshita, H.; Ihara, F. and Nihira, T. (2010). Geranylgeranyl diphosphate synthase genes in entomopathogenic fungi. Appl. Microbiol., 85: 1463-1472.

Strasser, H.; Abenstein, D.; Stupper, H. and Butt, T.M. (2000). Monitoring the distribution of secondary metabolites produced by the entomogenous fungus Beauveria brongniartii particular reference to oosporein. Microbiol. Res.,104: 1227-1233.

Suffness, M. and Pezzuto, J.M. (1990). Assays related to cancer drug discovery. In:" Methods in Plant Biochemistry, Assays for Bioactivity." Hostettmann, K. (Ed.). Academic Press, London, pp. 71-133.

Vey, A.; Hoagland, R. and Butt, T.M. (2001). Toxic metabolites of fungal biocontrol agents. In: "Fungal Biocontrol Agents." Butt, T.M.; Jackson and Magan, N. (Eds.). Progress Problem and Potential. CABI, Wallingford pp. 311-346.

Viarengo, A. and Canesi, L. (1991). Mussels as biological indicators of pollution. Aquac., 94: 225-243.

WHO (1965). Molluscicide screening and evaluation. Bull. World Healt. Org. Monograph Ser., 50: 124-138.

WHO (2008). African Network for drug/diagnostics discovery and innovation (ANDI) 'Creating a sustainable platform for R\&D innovation in Africa'.; $1^{\text {st }}$ meeting, Abuja, Nigeria.

WHO (2016). Schistosomiasis: number of people treated worldwide in 2014 . Weekly Epidemiological Record 91, 53-60. Available at: http://www.who.int/wer/2016/ wer 9105.pdf.

Zhang, C.; Wang, J.; Yang, H.; Wei, D.; Hu, F. and Fan, M. (2010). Evaluation on the antioxidant activity of extracts from strains of Beauveria bassiana. Zhongguo Weishengtaxixue Zazhi/Chinese J. Microecol., 22:417419.

Zhang, Q.; Wu, J.; Hu, Z. and Li, D. (2004). Induction of HL-60 apoptosis by ethyl acetate extract of Cordyceps sinensis fungal mycelium. Life Sci., 75: 2911-2919. 